\title{
S-I-7 冠動脈病変を伴う弁膜疾患の外科治療
}

一手術成績と心筋保護法よりの検討一

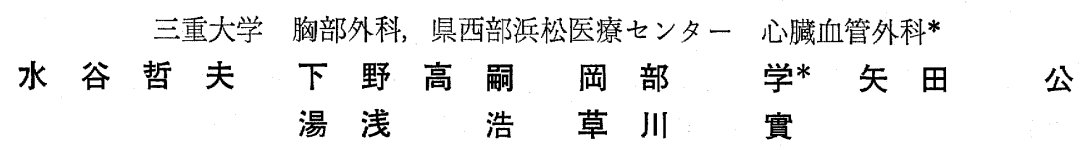

手術成績の向上や心筋保護方法の発達に伴いいままで は手術対象亡ならなかった高龄者弁膜症の手術例が増 え, その結果, 冠状動脈に狭窄病変を合併する頻度が高 まっている．また，UCG など非侵襲的な診断機器の進 歩により冠状動脈硬化に伴った二次性僧帽弁閉銷不全症 も多く竝断されるようになった。

本稿では，冠状動脈病変と弁膜病変を合併した疾患に 対する当科の手術成績を明ら加にし, 同時に外科治療上 の基本姿勢について述べる.

\section{対 象}

当科で経験した冠状動脈病変と弁膜病変を合併した疾 患は全部で 26 例であり，乙れを冠状動脈狭窄症（75\% 以上の狭窄 $)+$ 後天性弁膜症 $<I$ 群 $>$, 冠状動脈狭窄症 十二次性僧帽弁閉鎖不全症 (Sellors II 度以上の逆流) $<$ II 群 $>$, 大動脈炎症候群 $<$ III群 $>$ にわけ, 各群の特 徵・手術術式と手術成績・遠隔成績・ 筋保護方法など について検討した.

\section{成 績}

\section{1. 冠状動脈狭窄症十後天性弁膜症 $<$ I 群 $>$}

1980 年 1 月以降当科で外科治療を行った後天性弁膜 症は 430 例で，そのうち冠状動脈に $75 \%$ 以上の狭窄を
認めたのは 11 例 $(2.6 \%)$ で, 男 9 例, 女 2 例である. 平均年齢は 57.0 歳で, 冠状動脈狭窄を合併しない弁膜 症の平均年齢（51.9 歳）より, 明らかに高かった. ま た 1 人当りの狭窄病変数は 1.6 枝であった.

大動脈弁置換術のみ行ったのは 3 例，大動脈弁置換術 に A-C バイパス術を併用したのが 5 例で, うち1例を 出血でなくした，僧帽弁置換術のみ行ったのは 1 例，僧 帽弁置換術に A-C バイパス術を併用したのは 2 例で, 手術死はなかった. 結局, 11 例中 1 例, $9.1 \%$ の手術死 亡率で, 冠状動脈狭窄を合併しない弁膜症の手術死亡率 （4.2\%）より高かった（表 1). 弁置換術のみに終わっ た 4 例中 3 例では, 狭窄部より末梢の run-off が不良 で ungraftable と判断した. 残る 1 例では, 術前の造 影が淡く segment 6 の狭窄を $50 \%$ 之読みバイパス術 を行わなかった。

\section{2. 冠状動脈狭窄症十二次性僧帽弁閉鎖不全症} $<$ II 群 $>$

動脈硬化性の冠状動脈狭窄症に Sellors II 度以上の二 次的な僧帽弁閉銧不全を伴ったのは 13 例あり, 302 例 の虚血性心疾患手術例の $4.3 \%$ であった，平均年齢は 54.7 歳で, 狭窄病変数は 1 人当り 2.1 枝となっており I 群の 1.6 枝より多かった，また，心室瘤の合併が 12 例中 11 例 (85\%) にみられ大きな特徴であった.

表 1 手術成績（I群）

\begin{tabular}{|c|c|c|c|}
\hline 式 & 数 & 手術死 & 遠隔死 \\
\hline 大動脈弁置換術のみ & 3 & 0 & 0 \\
\hline 大動脈弁置換術＋A-C バイパス術 (RCA) & 3 & 0 & 0 \\
\hline 大動脈弁置換術+A-C バイパス術 (LAD) & 2 & 1 (出血) & 0 \\
\hline 僧帽弁置換術のみ & 1 & 0 & $1\left(\begin{array}{l}\text { 術後 } 2 \text { 加月 } \\
\text { 吸不全 }\end{array}\right)$ \\
\hline 僧帽弁置換術＋A-C バイパス術 (LAD+CX) & 1 & 0 & $1($ 術後 4 加月 $)$ \\
\hline 僧帽弁置換術＋A-C バイパス術 (LAD) & 1 & 0 & 0 \\
\hline 計 & 11 例 & 1 例 (9.1\%) & 2 例 \\
\hline
\end{tabular}


表 2 手術成績（II群）

\begin{tabular}{|c|c|c|c|}
\hline 式 & 数 & 手術死 & 遠隔死 \\
\hline 心室瘤切除術のみ & 1 & 0 & 0 \\
\hline 心室瘤切除術＋僧帽弁輪形成術 & 1 & 0 & 0 \\
\hline 心室瘁切除術+僧帽弁輪形成術+A-C バイパス術 & 1 & 0 & 0 \\
\hline 心室瘤切除術十僧帽弁置換術 & 1 & 0 & 0 \\
\hline 心室瘤切除術+A-C バイパス術 & 7 & 0 & 2 (心不全) \\
\hline 僧帽弁輪形成術＋A-C バイパス術 & 2 & 1 (紅皮症) & 0 \\
\hline 計 & 13 例 & 1 例 (7.7\%) & 2 例 \\
\hline
\end{tabular}

表 3 心筋保護法と術中心筋梗塞

\begin{tabular}{|c|c|c|c|c|c|}
\hline Stage & Topical cooling & Core cooling & $\begin{array}{l}\text { Cold blood } \\
\text { cardioplegia }\end{array}$ & $\begin{array}{l}\text { Nitroglycerin } \\
\text { Nicardipine }\end{array}$ & PMI \\
\hline $\begin{array}{ll}\text { I. } & (1974.7 \sim 1978.10) \\
\text { Intermittent aortic cross-clamp } \\
\text { II. }(1978.11 \sim 1983.12)\end{array}$ & cold water & $32^{\circ} \mathrm{C}$ & $(-)$ & $(-)$ & $33.3 \%$ \\
\hline $\begin{array}{l}\text { Potassium cardioplegia } \\
\text { III. (1984. } 1 \text { 以降) }\end{array}$ & slushed ice & $25^{\circ} \mathrm{C}$ & $(-)$ & $(-)$ & $17.9 \%$ \\
\hline $\begin{array}{l}\text { Nitroglycerin Ca-antagonist } \\
\text { cardioplegia }\end{array}$ & slushed ice & $25^{\circ} \mathrm{C}$ & $(+)$ & $(+)$ & $4.7 \%$ \\
\hline
\end{tabular}

心室瘤切除術のみを行ったのは 1 例だけで，心室瘤切 除術江僧帽弁置換術あるいは弁輪形成術の併用を 3 例 に，心室瘤切除術に A-C バイパス術の併用を 7 例に行 った．また，心室瘤を伴わない 2 例に対しては，僧帽弁 輪形成術と A-C バイパス術を同時に行った，手術死は 紅皮症にて術後 21 日目に死亡した 1 例（7.7\%）のみ で，心臟死はなかった（表 2 ).

術後遠隔期に問題をきたしたのは 6 例で，いずれも心 室瘤切除術に A-C バイパス術を併用した例であった。 そのうち 2 例では乳頭筋自身便塞を認め, 術後もII度 以上の僧帽弁逆流が残っており, 術後 8 年および術後 1 年経過後に心不全で死亡した．また別の 2 例では，手術 時には軽かった回旋枝病変が進行したため術後 7 年およ び術後 4 年目に再梗塞をきたし，そのうち 1 例は死亡し た. 他に術後 5 年経過後の突然死を 1 例, 脳卒中の発症 を 1 例みている.

\section{3. 大動脈炎症候群 $<$ III群 $>$}

いわゆる大動脈炎症候群で冠状動脈狭窄を伴ったのを 2 例経験している. 症例 1 は 39 歳の男性で, $\mathrm{N}$ 度の大 動脈弁閉鎖不全を認めたが回旋枝の狭窄が $50 \%$ 以下と 軽かったので，ステロイドにて炎症をコントロールした のち大動脈弁置換術のみ行った，症例 2 は 17 歳の女性 で, 右冠状動脈の起始部に 75\%, 左冠状動脈起始部に 99\%の狭窄を認めた. しかし大動脈弁閉銷不全が I 度 之軽かったので上行大動脈より segment 2 および 6 へ
2 枝バイパス術のみ行った.

症例 1 は，手術 1 年後に人工弁感染をきたしたため再 弁置換術を余儀なくされたが, 症例 2 は術後 1 年 5 か月 の現在, 経過良好である.

\section{4. 心筋保護法と術中心筋梗塞}

術中心筋梗塞を 26 例中 2 例（7.7\%）にみた.

今回対象とした 26 例を含んだ虚血性心疾患すべてに おける術中心筋梗塞の発生頻度を心筋保護法別倹討し た. 間欠的大動脈遮断で行っていた stage I (1978 年 10 月まで) では $33.1 \%$ と高い梗塞発生率をみていた が, Potassium cardioplegia を用いるようになった stage II では $17.9 \%$ に減った. さらに nitroglycerin Ca-antagonist cardioplegia $\&$ cold blood cardioplegia を用いるようにした 1984 年以降の stage III で は，4.7\% まで下げることができた(表 3 ).

\section{考察}

後天性弁膜症之虚血性心疾患との合併例に対する手術 適応は，原則的にはおのおのに対する手術適応と同じで ある. ただ，両疾患の合併例では，弁膜症による心不全 症状が前面に出るため狭心症状が隠されるととが多く, 胸痛発作がないのを理由に選択的冠状動脈造影を行わな かったり, 冠血行再建術の適応からはずすのは適切では ない．Czer ら は，冠状動脈病変を合併した僧帽并置 換術群よりあ合併しない群のほうが手術成績・遠隔成績 
ともに良いのを報告している．しかし冠状動脈病変合併 例でも冠血行再建術を積極的比併用するととにより遠隔 成績のみでなく手術成績の向上む得ており，完全血行再 建術を勧めている。

虚血性僧帽弁開銷不全の原因としては，1）乳頭筋の 断裂，2）乳頭筋の虚血・線維化による収縮不全，3）左 室腔拡大による僧帽弁輪の拡大，4）心室瘤形成による 乳頭筋起始部の位置異常に伴った弁の接合不全，などが ある ${ }^{2,3)}$. したがって虚血性の僧帽弁逆流をコントロー ルするには症例でとにそのメカニズムを十分検討し，術 式を決める必要がある.

左心室瘤を伴う場合には，乳頭筋自身便塞や虚血が なくても左室の拡大による僧帽弁輪拡大や乳頭筋付着部 の収縮期異常運動により僧帽弁の接合不全をきたし，

Sellors I-II 度の逆流を呈する場合が多い，私たちは このような例では，瘤を十分切除して左室腔を縮小する とともに可能な限りの冠血行再建を加えることにより逆 流をコントロールしている. しかし術後にII度以上の逆 流が残り心不全死した 2 例ではいずれす乳頭筋自身にす 梗塞が执よんでいたととにより，乙のような例では僧帽 弁置換術により逆流を確実にコントロールすべきである と考えている.

左心室瘤を伴わない場合の僧帽弁逆流では prolaps を きたしやすく，Kay ら ら)はこのような虚血性僧帽弁閉 鎖不全に対し腱索形成術と弁輪形成術を併用するととに より逆流は十分コントロールでき,また術後遠隔期の生 存率や event-free ratio 屯弁置換群より優れていると述 べている. 私たちあ下壁梗塞後に Sellors III度の僧帽弁 閉銧不全を認めたので後交連部の弁輪形成術と segment 8 および 14 への 2 枝バイパス術を行い, 術後 I 度にコ ントロールされた 44 歳の男性例を経験しており, 弁輪 搪大が強く弁自身の変化が少ない例では試みるべき術式 之考えている.

本合併疾患群に対する心筋保護法は, 虚血性心疾患単 独の場合と同じであり，その詳細はすでに述べた5)。そ の特徴は, ニトログリセリンとニカルジピンを手術当日 早朝より術中はもちろ九第 2 病日まで経静脈性に持続投 与することである. また大動脈遮断中は咽頭温を 25 度 に保ち，30 分ごとにてれらの薬剤を含んだ cold blood cardioplegia を大動脈の基部および末梢側吻合の終わ
ったグラフトより注入し，心筋保護液の不均衡分布に対 処している．乙のような方法により再灌流時の心筋障害 や術中 spasm などの発生防止任努めており, 術中心筋 梗塞の発生頻度を $4.7 \%$ まで低下させるととができた.

しかし梅毒性大動脈炎や大動脈炎症候群では，冠状動 脈入口部汇高度の狭窄病変をきたしやすく心筋保護液の 初回投与法が問題となる.私たちは乙のような例では core cooling により咽頭温を $30^{\circ} \mathrm{C}$ まで下げたのち大動 脈を遮断し，ヤング氏液を大動脈基部あるいは冠状動脈 内に注入して速やかな心停止を得ている. 最近では冠静 脈洞より逆行性に心筋保護液を注入する retrograde cardioplegia の方法屯開発され，いくつかの問題点を を含んではいるものの今後試みるべき方法の一つと考え ている.

\section{結論}

1）後天性弁膜症 430 例中, $75 \%$ 以上の 冠状動脈狭窄 を 11 例 $(2.6 \%)$ 飞認めた.

2) 後天性弁膜症では積極的に冠状動脈造影を行って 冠病変の発見に努め, 75\%以上の狭窄を示す例では A-C バイパス術を併用するのが望ましい。

3）虚血性心疾患 302 例中, Sellors III 度以上の二 次性僧帽弁閉鎖不全を 13 例 (4.3\%) 飞認め, そのう ち 11 例では心室瘤を合併していた。

4) Sellors III 度以上の僧帽弁閉鎖不全を伴った心室 瘤においては，十分な心室瘤切除と弁置換術による逆流 のコントロールにより臨床症状の改善や遠隔成績の向上 が得られる。

5）心室瘤を伴わない Sellors III度の僧帽弁閉銷不全 に対しては，腱索および弁輪形成術により逆流をコント ロールできる場合がある.

6) Nitoroglycerin $\mathrm{Ca}$-antagonist cardioplegia $は$ 心筋保護に有用であり, 術中心筋梗塞の発生を低下させ ることができた。

文 献 1) Czer, L. S.C. et al.: Circulation 70 (Suppl. 1): 1, 1984. 2) Kay, J. H. et al.: Am. Heart J. 96: 253, 1978. 3) Ogawa, S. et al.: Am. Heart J. 97: 312, 1979. 4) Kay, G. L. et al. : Circulation 74 (Suppl. 1): 1, 1986. 5）水谷哲夫ほか：臨床胸部外科 $6: 447,1986$. 